\title{
Mellan två språk
}

Språkförbållanden i 1800-talets Östermark: fallet Wilhelm Forsman (1781-1865)

Wilhelm FoRsman (I78I-I865) кOM FRÅN en lärd prästsläkt och var född och uppvuxen i byn Östermark i Södra Österbotten, där han också tillbringade största delen av sitt liv. I Wilhelms far, kyrkoherden i Östermark Johan Forsmans (d. I8Io) släkt var det många som på I8oo-talet blev betydande rättslärda och aktörer på det vetenskapliga och politiska området. Även Wilhelm följde släktens traditioner och studerade först vid Vasa trivialskola (I794-I80I) och skrevs sedan in vid Akademien i Åbo år I8o2. Till skillnad från sin far och många andra män i släkten blev han inte präst trots att han var student. År 1807 rekryterades han till Vasa regemente och deltog därefter i I808-I809 års krig som sergeant. Efter att han hade återvänt från kriget verkade han från och med slutet av I8I8 som kyrkväktare i sin framlidne fars hemförsamling Östermark. Senare nämns han i skrifteböckerna också som torpare under prästgården. ${ }^{1}$ Även i valet av maka skilde sig Wilhelm från många av de andra männen i släkten, vars hustrur

Den här artikeln är en del av mitt projekt "Wilhelm Forsman: från samhällselit till torpare. En mikrohistorisk undersökning av agentskap och svenska släktnätverk i I80o-talets Österbotten” som Svenska litteratursällskapet i Finland har stött med medel ur Ragnar, Ester, Rolf och Margareta Bergboms fond.Jag tackar Svenska litteratursällskapet i Finland för stödet. Jag tackar också redaktörerna samt artikelns anonyma granskare för deras kommentarer.

I. Se Yrjö Kotivuori, "Ylioppilasmatrikkeli I640-I852: Vilhelm Forsman”, nätpublikation 2005, https://ylioppilasmatrikkeli.helsinki.fi/henkilo.php?id=II59I (hämtad I8/II 20I9), där Wilhelm benämns "kyrkväktare" först I832. Officiellt valdes han emellertid till kyrkväktare vid sockenstämman 4/ro I8I8. Östermark församlings arkiv (härefter ÖFA), Socken- och kyrkostämmoprotokoll I804-I82I (IBa:I), del 8I, Riksarkivet: http://digi.narc.fi/digi/view.ka?kuid=755874I (hämtad I4/4 2020). 
kom från betydande svenskspråkiga släkter. Wilhelm, som ända till krigsslutet hade tjänstgjort vid Vasa regemente, återvände hösten I8o9 till hembygden från andra sidan Bottniska viken och ingick ganska snart äktenskap med den lokala torpardottern Clara Johansdotter. ${ }^{2}$ Wilhelms egna barn slog inte längre in på den lärda banan: de blev drängar och pigor.

I denna artikel granskar jag förhållandet till svenskan i den i huvudsak finskspråkiga kyrksocknen Östermark under I8oo-talets första hälft. Jag närmar mig ämnet via en fallstudie: i centrum står Wilhelm Forsman, vars liv man kan se som en fruktbar anomali, det vill säga ett ovanligt, överraskande och otypiskt objekt för historisk forskning. Ynglingen från den lärda svenskspråkiga släkten slog in på den lärda banan, men följde till slut inte den väg som i regel var utstakad för dem som tillhörde hans stånd. I och med honom övergick i stället den östermarkska grenen av den Forsmanska släkten från herrskapsklassen till allmogeklassen och förfinskades också inom kort. Wilhelms liv kan därmed ses som ett slags mellanskede, där förhållandet till svenskan i Wilhelms släkt ändrades. Genom att studera Wilhelms fall är det möjligt att, förutom att få en djupare förståelse av detta enskilda fall, också få en ökad förståelse av ståndspersoners språkförhållanden i ett landsbygdssamhälle under en tidsperiod som på samhällelig nivå präglades av olika ideologiska förändringar i förhållande till språken. I början av tidsperioden efter I808-I809 års krig var den svenskspråkiga samhällseliten i romantikens anda influerad av tankar om en nation med ett språk (finska). I slutskedet, från och med i850-talet, började man inom eliten också intressera sig för den svenskspråkiga allmogen, vars historia tidigare inte hade väckt intresse bland svenskspråkiga ståndspersoner. $^{3}$

Östermark i Södra Österbotten utgör den lokala kontexten för undersökningen. Enligt den sockenindelning som gjordes i början på I8oo-talet gränsade Östermark till Ilmola i öst, Österland i norr,

2. Faktorer som möjligen inverkat på Wilhelms icke ståndsmässiga äktenskapsval undersöker jag i ett annat sammanhang.

3. Se till exempel Johanna Wassholm, Svenskt, finskt och ryskt: nationens, språkets och bistoriens dimensioner hos E.G. Ehrström I808-I835, Helsingfors: Svenska litteratursällskapet i Finland 20I4, s. 6I-68. 
Bötom som hörde till Lappfärd i söder och Kristinestad (landskommunens område) i väster, samt Pörtom i nordväst. År I80o hörde Östermark i kyrkligt, förvaltningsmässigt och juridiskt avseende till svenskspråkiga Närpes storsocken och tingslag. I officiella dokument nämns Östermark i anknytning till Närpes första gången på 1570-talet. Den från Närpes sett östra (ödemarks)bygden skilde sig emellertid från de andra kustområdena i modersocknen inte bara till sin näringslivsstruktur utan också språkligt i och med att huvuddelen av befolkningen var finskspråkig. Språkskillnaden ledde så småningom till att östermarkborna i slutet på r6oo-talet drev igenom sitt krav på en egen kapellförsamling med tillhörande kaplan. År 1795 blev Östermark ett självständigt pastorat, vars första kyrkoherde var Johan Forsman, som tidigare skött kaplanstjänsten. ${ }^{4}$ Bosättningen i Östermark var koncentrerad till olika delar av kyrksocknen, som år I817 officiellt delades in i sex byar: Kyrkoby, Perälä, Riip-Öist, Horo (Hårå), Järvenpää-Närvijoki och Nori. Östermark skildes från Närpes kommunalförvaltning och församling några år efter Wilhelms död, det vill säga år 1868, då Teuva kommun bildades. ${ }^{5}$

För svenskans del innebar den nya kommunbildningen inte en omedelbar minskning av svenskans betydelse i officiella sammanhang. I Östermark hade finsksinne och viljan att öka bruket av finska i officiella sammanhang börjat tillta först under Wilhelms sista levnadsår och efter hans död. Sockenstämmans protokoll började föras på finska från och med november 1866, efter den tidigare kyrkoherden, prost Matias Kumlins ( $1787-1866)^{6}$ död. Innan dess hade några bouppteckningar uppgjorts på finska från och med slutet av 1840-talet, men

4. Raimo Ranta,"Kanta-asutuskaudelta vuoteen I795", Raimo Ranta \& Teuvan historiatoimikunta (toim.), Teuvan historia vuoteen 1795 , Teuva: Teuvan kunta \& Teuvan seurakunta 1994, s. 70-72, 270-274.

5. Senare räknade man att Östermark bestod av nio byar: ny var Kauppila, samt nu som separata byar Riip, Öist, Järvenpää och Närvijoki. Raimo Ranta, "Kirkkopitäjästä omaksi kunnaksi I796-ı9ı3", Raimo Ranta \& Teuvan historiatoimikunta (toim.), Teuvan historia vuodesta 1796 vuoteen I953, Teuva: Teuvan kunta \& Teuvan seurakunta 2006, s. 68-70, 408-4I9.

6. Yrjö Kotivuori, "Ylioppilasmatrikkeli I640-I852: Matias Kumlin”, nätpublikation 2005 https://ylioppilasmatrikkeli.helsinki.fi/henkilo.php?id=I2205 (hämtad I6/4 2020). För Kumlins del saknas i studentmatrikeln uppgifter om att denne även åren I8I4-I8I7 arbetade i Östermark, då som pastorsadjunkt. 
tjänstemännens korrespondens förblev i huvudsak svenskspråkig fram till r88o-talet, trots att Östermark skildes från Närpes. ${ }^{7}$

Även om Östermark till största delen var en finskspråkig socken, fanns ännu på I8oo-talet en svenskspråkig befolkning på området. Enligt Holger Walléns undersökning från 1932 av språkgränser och svenskspråkiga områden i Finland omkring 1600-1865 har den svenskspråkiga befolkningen i Östermark i synnerhet bott i byn Perälä som gränsar till Närpes. ${ }^{8}$ Byn har på så sätt tidvis kunnat utgöra det som Christer Kuvaja betecknar som en tvåspråkszon, där finsk- och svenskspråkiga har bott sida vid sida. ${ }^{9}$ Utifrån materialet hölls emellertid sällan svenskspråkiga gudstjänster under den undersökta perioden i Östermark. Det tyder på att det funnits få svenskspråkiga i Östermark på I700- och I80o-talen i förhållande till den totala folkmängden. ${ }^{10}$ I Östermark kan man emellertid inte tala om en språkgräns, eftersom språkgräns som begrepp bär en inbyggd föreställning om att det knappt alls skulle ha förekommit samarbete och handel eller annan social och kulturell växelverkan mellan de finsk- och svenskspråkiga områdena, utan att de skilda språkliga bosättningarna skulle ha legat

7. Ranta, "Kirkkopitäjästä omaksi kunnaksi I796-I9I3", s. 392-393, anger att övergången till finskspråkiga protokoll skedde under kyrkoherde Lars August Palonens (I837-I908) tid. Det första sockenstämmoprotokollet på finska är daterat II/II I866, då Mauritz Edvard Caselius (I830-I87I) fungerade som tillförordnad kyrkoherde efter Kumlins död. ÖFA, Socken- och kyrkostämmoprotokoll I845-I89I (IICa:2), del 69: 2/6 I867, Riksarkivet: http://digi.narc.fi/digi/view.ka?kuid=7574429 (hämtad $23 / 42020$ ).

8. Holger Wallén, Språkgränsen och minoriteterna: i Finlands svenskbygder omkr. I6ooI865, Åbo: [s.n.] I932, s. 40-4I, 356-357. Man bör förhålla sig kritiskt till Walléns undersökning, eftersom Wallén stundtals har läst sitt omfattande källmaterial något ytligt.

9. Om termen tvåspråkszon se Christer Kuvaja,"Språkgräns - verklighet eller myt? Finskt och svenskt i Norrbotten och Östra Nyland under senare hälften av I7ootalet”, Max Engman \& Nils Erik Villstrand (red.), Maktens mosaik. Enhet, särart och självbild $i$ det svenska riket, Helsingfors: Svenska litteratursällskapet i Finland \& Stockholm: Atlantis 2008, s. 285-287, 312-313.

Io. I slutet på I7oo-talet hölls svenskspråkiga gudstjänster ett antal gånger i året $\mathrm{i}$ Östermark, men till exempel i början av I80o-talet var gudstjänsterna bara på finska. Wallén, Språkgränsen och minoriteterna, s. 357 (uppgiften gäller år I773); Prostvisitationens protokoll 6/5 I804 (§ I3), ÖFA, Protokoll från prostvisitationer I796-I857, del 7, Riksarkivet: http://digi.narc.fi/digi/view.ka?kuid=8379239 (hämtad I8/II 20I9). 
och bevarats relativt avskilda från varandra. ${ }^{11}$ Människorna i Östermark och Närpes har emellertid i sökandet efter arbete flyttat från det ena området till det andra, och innan Teuva kommun bildades I868 har det tidvis förekommit täta kontakter till modersocknen. Också de observationer som gjorts i senare forskning om dialekten i Östermark och Närpes vittnar om tidiga och kontinuerliga kontakter och växelverkan. När man undersökt dialekter och ortnamn i Östermark har man observerat en riklig växelverkan mellan den finsk- och svenskspråkiga befolkningen på området under årens lopp, även om det under olika tidsperioder inte nödvändigtvis förekommit dagligt umgänge språkgrupperna emellan. I gammal finsk Östermarkdialekt har det förekommit många influenser från svenskan och i synnerhet Närpesdialekten. ${ }^{12}$

Östermarkbon Wilhelm Forsman som står i centrum för detta arbete är utmanande som forskningsobjekt, eftersom han inte har lämnat efter sig autobiografiska källor. Inte heller har personligt, skriftligt eller annat material bevarats, där han medvetet skulle ha lyft fram sitt förhållande till svenskan. Det som finns kvar efter Wilhelm är i huvudsak spår - ledtrådar - som andra, och i ett antal fall han själv, lämnat i officiella dokument. Huvudmaterialet i min undersökning om Wilhelm består av dokument i Östermark församlings arkiv. Genom kritisk granskning och närläsning försöker jag i spåren efter Wilhelm gestalta de åsikter som framträder om hans förhållande till svenskan i I8oo-talets Östermark.

II. Om begreppet språkgräns och kritiken av det, se Kuvaja, "Språkgräns - verklighet eller myt?", s. 285-287, 312-313; Christer Kuvaja, "Språkkontakt och tvåspråkighet i I700- och I80o-talens Finland", Marika Tandefelt (red.), Finländsk svenska från medeltid till I860, Helsingfors: Svenska litteratursällskapet i Finland 20I9, s. 318.

I2. Svenskans och i synnerhet Närpesdialektens inflytande på Östermarkdialekten har Saija Tamminen undersökt i sin avhandling pro gradu, Svensk påverkan på Teuvadialekten, opublicerad avhandling pro gradu i nordiska språk, Helsingfors universitet 2003. Förutom att analysera talad och skriven I90o-talsdialekt har Tamminen undersökt svenskans inflytande på lokala ortnamn. Enligt henne förekommer många lånord från svenskan och Närpesdialekten, samt uttryck som har direkt svenskt ursprung. Därtill har den lokala dialekten tagit intryck av svensk ordföljd. Ett annat tecken på växelverkan är verbformer som är typiska för och som endast förekommer och används på samma sätt i Närpes- och Östermarkdialekt. Med Tamminens ord (s. 57): "Svenskan och finskan har närmat sig varandra i Teuva." 
Jag undersöker vilket förhållandet till svenskan var i Wilhelms föräldrars släkter och hur det avspeglar sig i Wilhelms eget språkförhållande, i vilken grad språk i landsbygdssamhällen som Östermark överhuvudtaget var en faktor som skilde och kategoriserade människor och därmed påverkade en individs självbild, samt vad Wilhelms efterkommandes språk och livsskeden kan berätta om Wilhelms förhållande till svenskan. Jag hävdar att Wilhelms förhållande till språk i stor utsträckning följer de linjer som kännetecknar hans anmödrars och anfäders språk och att samma förhållande i viss mån även gick $i$ arv till hans barn. Förhållandet till språk bestämdes av vad språket användes till: det var viktigt att bli förstådd i olika språkbrukssituationer och i olika sociala sammanhang. Man kommunicerade med hjälp av språket, men det att man talade finska eller svenska, eller båda språken, var inte det enda som definierade vem individen var. Sannolikt behöll Wilhelm livet ut ett emotionellt band till svenskan uttryckligen som ett lärdomsspråk. Detta språk för det lärda ståndet överfördes emellertid inte till hans efterkommande, för vilka svenskan blev ett folkspråk.

FörhÅLLANDET TILL SPRÅK I SLÄKTERNA Forsman OCH AchtMan

På fadern Johan Forsmans sida av släkten hade man ännu på 180o-talet svenska som modersmål. Förutom Wilhelms far tjänade också andra män i släkten kyrkan som kaplaner och kyrkoherdar på områden som hade en finskspråkig majoritet eller där befolkningen i huvudsak var finskspråkig. Ett exempel är Wilhelms farbror Georg Forsman (I726I789) som var kaplan i sin födelsesocken Kannus samt kyrkoherde i Laihela (prost från och med I 788 ). ${ }^{13}$ På dessa områden var kunskaper

I3. Yrjö Kotivuori, "Ylioppilasmatrikkeli r640-I852: Georg Forsman", nätpublikation 2005, https://ylioppilasmatrikkeli.helsinki.fi/henkilo.php?id=7253 (hämtad I7/ıo 2019). Enligt Holger Wallén låg Laihela på gränsen mellan språkområdena men var finskspråkigt, även om det kunnat förekomma också svenskspråkig bosättning där. Wallén, Språkgränsen och minoriteterna, s. 42, 44-46. Se också artiklar i matrikeln om t.ex. Georg Forsmans söner Zachris och Johan, samt Zachris son Oskar Vilhelm, som verkade som kaplaner och kyrkoherdar i t.ex. Vetil, Lillkyro, Laihela, samt Jurva och Storkyro. Yrjö Kotivuori,"Ylioppilasmatrikkeli I640-I852: Zachris Forsman", nätpublikation 2005, https://ylioppilasmatrikkeli.helsinki.fi/ 
i finska en förutsättning för att kyrkliga och civila tjänstemän skulle kunna sköta sin tjänst. I synnerhet prästerna hade en betydande roll $i$ att förmedla information från statsapparaten och länsstyrelserna till folket. Prästerna läste i samband med gudstjänsterna upp officiella kungörelser för församlingsborna. De tolkade innehållet i svenskspråkiga dokument för sådana som inte kunde språket och översatte också ofta svenskspråkiga myndighetskungörelser till finska. Kungörelserna sändes nämligen inte nödvändigtvis till församlingarna färdigt översatta till finska trots att en kunglig förordning redan 1732 hade stipulerat att kungörelserna skulle sändas ut till församlingarna på det språk på vilket de lästes upp i kyrkan. ${ }^{14}$ I Östermark fick man antagligen vänta på kungörelser översatta till finska åtminstone till efter grundandet av Teuva kommun, eftersom den dåtida tillförordnade kyrkoherden Lars August Palonen (1837-I908) ännu I868 prövade myndigheternas tålamod genom att vägra kungöra förordningar och påbud om de inte levererades till församlingen på finska. ${ }^{15}$

Även om kunskaperna i finska därmed var en förutsättning för att verka i tjänsten som kaplan och kyrkoherde i Östermark, torde umgänget med den svenskspråkiga grenen av släkten Forsman som bodde vid kusten emellertid ha varit regelbundet så länge Johan Forsman levde och ännu ett antal år efter hans död. Fadern Johans kusin och Wilhelms namne, borgmästaren i Kaskö Wilhelm Forsman (d. 1815), tjänstgjorde fram till I8I5 som sockenskrivare i Närpes och därmed

henkilo.php?id=9907 (hämtad ı7/ı 20I9); Yrjö Kotivuori, "Ylioppilasmatrikkeli I640-I852: Johan Forsman", nätpublikation 2005, https://ylioppilasmatrikkeli. helsinki.fi/henkilo.php?id=9384 (hämtad I7/ıo 20I9); Yrjö Kotivuori, "Ylioppilasmatrikkeli 1640-I852: Oskar Vilhelm Forsman", nätpublikation 2005, https:// ylioppilasmatrikkeli.helsinki.fi/henkilo.php?id=I4856 (hämtad I7/ı 20I9).

I4. Gunnar Suolahti,"Suomen kansallisuus- ja kieliolot I70o-luvulla", Gunnar Suolahti, Vuosisatain takaa. Kulttuuribistoriallisia kuvauksia I500-I80o-luvuilta, Helsinki: Suomalaisen Kirjallisuuden Seura I993, s. 312-3I3, 318-3I9; Nils Erik Villstrand, "Skriftlighet med förhinder. Den svenska statsmaktens kungörelser i finskspråkiga församlingar under 1700-talet", Max Engman \& Nils Erik Villstrand (red.), Maktens mosaik. Enhet, särart och självbild $i$ det svenska riket, Helsingfors: Svenska litteratursällskapet i Finland \& Stockholm: Atlantis 2008, s. 322-329, 345-252 samt passim om problem i anslutning till översättningen av dokument till finska, som bristen på resurser att anställa översättare samt avsaknad av ett standardiserat skriftspråk.

I5. Ranta, "Kirkkopitäjästä omaksi kunnaksi I796-I9I3", s. 392-393. 
även i Östermark, och i den uppgiften fick släktingen anledning att flera gånger om året besöka Östermark. ${ }^{16}$

Wilhelms släkt på mödernet var också tvåspråkig, men geografiskt tydligare koncentrerad till svenskspråkiga Österbotten. Morfadern Henric Achtman den äldre (ca I7I8-I765), kaplan i Östermark I744-I765 och son till en skomakare från Björneborg, hade till och med utmärkt sig som översättare. Han översatte Johann Baudewins (I64I-I699) ursprungligen tyskspråkiga verk Eltern und Kinder SeelenRettung från svenska till finska. Verket Wanbembain ja lasten sieluinpelastus utkom år $1752 .{ }^{17}$ Wilhelms morbröder, Henrik Achtman den yngre (I745-I8I6) och Alexander Achtman (I756-I8I7), som nämns som student i Åbo år I776 och i Uppsala år I778, valde en karriär inom kyrkan och verkade som kaplaner och predikanter i socknar längs den österbottniska kusten där svenskspråkiga var i majoritet. Henrik tjänstgjorde i Pörtom, där finskspråkiga gudstjänster inte hölls förrän på I8Io-talet, och Alexander i Maxmo, där finskspråkiga gudstjänster i inget skede hölls under den tidsperiod som behandlas i Holger Walléns undersökning. ${ }^{18}$ Av Wilhelms morbröder ägnade åtminstone predikanten i Pörtom Henrik Achtman den yngre även efter tiden vid Akademien sig åt vetenskapliga efterforskningar och delgav sina resultat på svenska, inte på latin. Antydningar om ett vetenskapligt intresse ger åtminstone avhandlingsmanuskriptet "Enfaldigt dock

I6. Ibid., s. 387. Denne Wilhelm Forsman var far till presidenten för Vasa hovrätt Johan William Forsman (I788-I883). Yrjö Kotivuori, "Ylioppilasmatrikkeli I640-I852: Johan William Forsman", nätpublikation 2005 https://ylioppilasmatrikkeli.helsinki. fi/henkilo.php?id=II935 (hämtad 23/4 2020).

I7. Yrjö Kotivuori,"Ylioppilasmatrikkeli I640-I852: Henrik Achtman", nätpublikation 2005, https://ylioppilasmatrikkeli.helsinki.fi/henkilo.php?id=6547 (hämtad I8/II 2019); Johann Baudewin, Wanhembain ja lasten sieluin-pelastus, [...] ruotzin kielestä suomexi käätty Henric Achtmannilda, Turku: Jacob Merckell I752, https://www.doria. fi/handle/Ioo24/130349 (hämtad 29/5 2020).

I8. Yrjö Kotivuori, "Ylioppilasmatrikkeli I640-I852: Henrik Achtman”, nätpublikation 2005, https://ylioppilasmatrikkeli.helsinki.fi/henkilo.php?id=8330 (hämtad I7/Io 2019); Yrjö Kotivuori,"Ylioppilasmatrikkeli r640-I852: Alexander Achtman", nätpublikation 2005, https://ylioppilasmatrikkeli.helsinki.fi/henkilo.php?id=9448 (hämtad I7/Io 20I9). Om Maxmo och Pörtom se Wallén, Språkgränsen och minoriteterna, s. 42-43, 50, 339, 344. Om Pörtom se också Kuvaja, "Språkkontakt och tvåspråkighet i I700- och I80o-talens Finland", s. 324. Från och med år I730 hörde Närvijoki (Österland) med finskspråkig befolkning till Pörtom, år I862 anslöts orten till Jurva. 
påliteligit sätt att göra god ost: inhämtadt af förfarnaste Ostgörerskor i östermarck Capell och Nerpes Sockn af Österbotn” av Henrik den yngre som var elev till professorn i ekonomi Pehr Kalm (I7r6-I779) och som år $\mathrm{I}_{7} 63$ skrev gratulatio $\mathrm{i}$ en doktorsavhandling som denne handlett. ${ }^{19}$ Av Wilhelms morbröder bodde just Henrik närmast sina släktingar i Östermark. Pörtom predikogäll, där Henrik tjänstgjorde från och med I782, blev en del av Östermark pastorat I796. Det finns anledning att anta att umgänget i någon mån bevarades åtminstone med denne moderns äldste bror.

Om man beaktar uppgifterna i Walléns undersökning av språkgränser och svenskspråkiga områden i Finland är det emellertid möjligt att Wilhelms mormor Margareta Sirelius (ca I72I-I795) var antingen tvåspråkig eller finskspråkig. Enligt Wallén var Vesijärvi i Storå, därifrån mormodern kom, ett finskspråkigt område. Till grund för påståendet har Wallén till exempel framfört att Siiro gård i Vesijärvi, som hade varit mormoderns hemgård, skulle ha haft mycket dåliga vägförbindelser till svenskspråkiga områden som Lappfjärd, och att Vesijärvi från och med I786 hörde till Storå finskspråkiga kapellförsamling. ${ }^{20}$ I senare forskning har man antytt att inflyttning antagligen förekom från Lappfjärdhållet till Vesijärvi. ${ }^{21}$ Utifrån dessa ganska fåtaliga informationsspillror är det emellertid omöjligt att närmare avgöra om mormodern hade några kunskaper i svenska, eller om hon talade och förstod endast finska.

På ett allmänt plan har man i varje fall ansett att det var mer sannolikt att ståndsmän var tvåspråkiga än att ståndskvinnor var det, eftersom de förra tjänstgjorde i offentliga och andra uppgifter, där växelverkan mellan språkgrupperna var större. I synnerhet på finsk-

I9. Nationalbiblioteket: Handskriftssamlingarna; Se H. Achtman den yngres gratulatio i Physico-oeconomisk afhandling, om kännemärcken til rika käll- och wattu-ådror, med philosophiska facultetens bifall, under oeconomiae professorens och Kongl. Swenska Wettenskaps Academiens samt Upsala Wettenskaps Societetens ledamots herr Pehr Kalms inseende. Utgifwen och til allmän granskning understäld af Christfried Ganander, Th.son Österbottninge, Åbo: J.C. Frenckell I763. Variant B: http://urn.fi/URN: NBN:fi-fd2or4-oooo34I8 (hämtad 29/5 2020).

20. Wallén, Språkgränsen och minoriteterna, s. 36-37.

2I. Kortfattat om sannolikheten för svensk bosättning i Vesijärvi by se t.ex. Mirjam Pihlaja, Isojoen pitäjän kirja, Vaasa: [s.n.] 1984, s. 28-29. 
språkiga områden kunde ståndspersoner vara aktivt tvåspråkiga. ${ }^{22}$ I kaplansgården och senare prästgården i Östermark torde det i varje fall ha funnits finskspråkigt tjänstefolk, som även ståndskvinnorna kommit i kontakt med. Bortsett från släktingar och de få ståndspersonerna i Östermark torde i synnerhet Wilhelms kvinnliga släktingar ha haft ganska få svenskspråkiga kontakter. ${ }^{23}$ Den starka närvaron i svenskspråkiga områden och inriktningen på vetenskap hos bröderna till Wilhelms mor Elisabeth Achtman (I750-I8I8) tyder emellertid på att man i Östermark prästgård på Achtmans tid under I7oo-talets första hälft möjligen talade svenska - trots att till exempel Henrik Gabriel Porthan senare (1793) hävdade att prästerskapet samt borgarna i städer och ståndspersonerna på landet ännu i början på I7oo-talet i huvudsak använde finska (men att läget nu hade förändrats). ${ }^{24}$ I ett brev till den tyska historikern August Ludwig von Schlözer 1779 hävdar emellertid Porthan att"alla ståndspersoner och de, som ens har fătt något slags uppfostran, förstår och talar också svenska." ${ }^{25}$ Fastän Wilhelms mor Elisabeth Achtman föddes och bodde i Östermark hela sitt liv och fastän hennes mors starkare eller enda språk kan ha varit finska är det alltså sannolikt att hon åtminstone behjälpligt har kunnat svenska, liksom hennes bröder och far. Beträffande bröderna kan man utgående från deras skriftliga arbeten och tjänstgöringsplats spekulera i huruvida de hade svenska som starkare språk.

I Östermark I8I6 där, med dåtida kyrkoherden Abraham Cajanus (I777-1828) ord, "alla öfverläggningar ske på Finska språket", ${ }^{26}$ har

22. Se till exempel Kuvaja, "Språkkontakt och tvåspråkighet i I7oo- och I8oo-talens Finland", s. 317, 319, 328, 331, 336, 342-343.

23. Se också Nils Erik Villstrand, Riksdelen: stormakt och rikssprängning 1560-I8I2, Helsingfors: Svenska litteratursällskapet i Finland 2009, s. I39; Christer Kuvaja, "Språkkontakt och tvåspråkighet i I7oo- och I8oo-talens Finland", s. 339-340, 344-345.

24. Suolahti,"Suomen kansallisuus- ja kieliolot I70o-luvulla,"s. 299. Porthans uttalande har ursprungligen utkommit i Äbo Tidningar 25/03 I793, s. 2, Nationalbibliotekets digitala samlingar: https://digi.kansalliskirjasto.fi/sanomalehti/binding/4090ı6? page $=2$ (hämtad ro/9 2020).

25. "[...] alle Leute von Stande, und die nur einige Erziehung genossen, verstehen und sprechen auch schwedisch." Se Ernst Lagus (red.), Breffrän Henrik Gabriel Porthan till samtida, Helsingfors: Svenska litteratursällskapet i Finland I898, s. 22, http://urn.fi/URN:NBN:fi-fd2or6-ooorıooo (hämtad ıo/9 2020).

26. Sockenstämmans protokoll $24 / 2$ I8I6 (no 2). ÖFA, Socken- och kyrkostämmoprotokoll I804-I82I (IBa:I), del 57, Riksarkivet: http://digi.narc.fi/digi/view. 
Wilhelm som prästson redan som liten vistats i en miljö där det förekom mycket umgänge på finska. Hans far torde redan å tjänstens och sina uppgifters vägnar ha haft tät kontakt med ortsborna. På den tiden fanns det många anledningar att besöka prästgården, om det sedan rörde sig om pass, bevis, fattighjälp eller sjukdom. ${ }^{27}$ Wilhelm har troligtvis lärt sig finska redan som barn i umgänget med grannar och tjänstefolk på prästgården. I Östermark förblev emellertid svenskan under Wilhelms livstid ett språk, som i vissa sammanhang hade större betydelse än finskan. Att man fortsättningsvis förutsatte kunskaper i svenska (vid sidan av finska) när man tillsatte civila och kyrkliga tjänster främjade språkets ställning och upprätthöll dess betydelse. ${ }^{28}$ Även för Wilhelm var svenska det språk som användes i officiella sammanhang. På svenska kunde Wilhelm hävda släktens rätt i juridiska angelägenheter, som år I807, då "Studenten Wilhelm Forsman" enligt Närpes tingsrätts protokoll ( $\$$ I63) företrädde sin gamle far i ett tvistemål. ${ }^{29}$ Som svenskkunnig underofficer hade Wilhelm möjlighet att i efterhand anhålla om obetalda lönefordringar från 1808-ı809 års krig via den så kallade lönefordringskommittén, som var verksam i Sverige åren $\mathrm{I} 8 \mathrm{IO}-\mathrm{I} 8 \mathrm{I} 2 .^{30}$

Eftersom Wilhelm kunde bägge språken och troligtvis båda aktivt, kunde han anpassa sitt språk efter situationen och smidigt förflytta sig från en social- och språkgrupp till en annan. Tvåspråkigheten gjorde det också möjligt att inta rollen som förmedlare; en sådan resurs och fördel torde behärskandet av två språk ha varit för Wilhelm redan

ka?kuid=7558718 (hämtad 3/4 2020). Om Cajanus se Yrjö Kotivuori, "Ylioppilasmatrikkeli I640-I852: Abraham Cajanus", nätpublikation 2005, https://ylioppilasmatrikkeli.helsinki.fi/henkilo.php?id=II282 (hämtad I8/ı 20I9).

27. Carin Bergström, Lantprästen. Prästens funktion i det agrara sambället $1720-I 800$, Nordiska museets handlingar IIo, Stockholm: Nordiska museet I99I, s. I7, 2I-22.

28. Ranta,"Kirkkopitäjästä omaksi kunnaksi I796-19ı", s. 388-393. Se också Suolahti, "Suomen kansallisuus- ja kieliolot I70o-luvulla," s. 293-294, 312-313.

29. Närpes vinterting $8 / 4 \mathrm{I} 807$ ( $\mathrm{I}_{1} 6_{3}$ ). Korsholms södra domsagas renoverade protokoll, protokoll för ordinarie ärenden $1807-1807$ ( $\mathrm{KO}$ a:2), del 234, Riksarkivet: http:// digi.narc.fi/digi/view.ka?kuid=23553552 (hämtad 23/3 2020).

30. Se anteckning om den utbetalda lönefordringen till Wilhelm i Finska lönefordringskommittén I8IO-I8I2, 7. Kvittensbok över utbetalta fältavlöningsmedel, I8I2 Januarii. Källa: FSHF:s bilddatabas: Sotilasasiakirjoja, Suomen palkkarästikomitea - Finska lönefordringskommittén, https://www.sukuhistoria.fi/sshy/index.htm (hämtad 22/4 2020). 
under 1808-I809 års krig. Då tjänstgjorde Wilhelm i Vasa regemente som en del av den tvåspråkiga femte brigaden under Sandels ledning. ${ }^{31}$

Nils Erik Villstrand, som undersökt språk och språkbruk i en I7oo-talskontext, har framhållit hur förhållandet till språk på den tiden var instrumentellt. Språk var av betydelse i kommunikation, där det viktiga var att förmedla sitt budskap så att man blev förstådd, samt att förstå en annans budskap. Inställningen till språket kunde emellertid skifta från en person och grupp till en annan, likaså kunde det skifta beroende på om förhållandet var frivilligt eller om det var förknippat med tvång. ${ }^{32}$ Språket hade alltså en social och kommunikativ funktion. ${ }^{33}$ Det instrumentella i förhållandet märks både i Wilhelms släkts och i hans eget förhållande till språk. Svenska var det språk som talades i Wilhelms släkt på både fädernet och mödernet och antagligen också i hans barndomshem, vilket möjliggjorde både informell kommunikation med släktingar och även bruket av svenska i officiella, inklusive litterära, sammanhang. Svenskan var oumbärlig också för dem som ville slå in på den lärda banan; kunskaperna i svenska möjliggjorde alltså Wilhelms studier vid trivialskolan och vid Kungliga Akademien i Åbo. ${ }^{34}$ Svenskan i egenskap av familjens och släktens språk var otvivelaktigt av emotionell betydelse för Wilhelm. Finskan var emellertid en förutsättning för att kunna verka i Östermark, liksom för att tjänstgöra som präst, vilket Wilhelms föräldrar otvivelaktigt i början hade berett sin son för. Finskan var emellertid inte förknippat med tvång, eftersom Wilhelm spontant torde ha tillägnat sig det i den finskspråkiga livsmiljön.

\section{SPRÅK SOM KATEGORI I ÖSTERMARK UNDER I 8OO-TALETS FÖRSTA H ÄLFT}

I början av Wilhelms livstid var ståndspersoner på en ideologisk nivå ännu inte intresserade av svensktalande allmoge och upplevde inte

31. Jussi T. Lappalainen, Lars Ericson Wolke \& Ali Pylkkänen, Suomen sodan historia I808-I809, Helsinki: Suomalaisen Kirjallisuuden Seura 2008, s. 98.

32. Villstrand, "Skriftlighet med förhinder", s. 350-35I.

33. Wassholm, Svenskt, finskt och ryskt, s. 77-78.

34. Om kunskaper i svenska som förutsättning för skolgång se Suolahti, "Suomen kansallisuus- ja kieliolot I70o-luvulla," s. 296. 
samhörighet med den ståndslösa del av befolkningen som talade samma språk. En fråga för sig är i vilken grad kunskaper i svenska eller finska eller båda språken överhuvudtaget var en särskiljande och kategoriserande faktor. Holger Wallén har i sin tidigare nämnda undersökning för Östermarks del inte uttömande reflekterat kring tvåspråkighetens betydelse. Förutom till de svenskspråkigas tidvis växande antal hänvisar man även till de tvåspråkigas relativa antal, till exempel i ett protokoll från en prostvisitation år I846 på kyrkoherde Matias Kumlins tid, där det konstateras att församlingsborna då försäkrat:

\begin{abstract}
Att Gudstjensten alltid hitintills skett å Finska språket. Men såwida genom inflyttningar på sednare tider, de Medlemmars i Församlingen antal, hwilka endast äro det Svenska språket mägtige, tilltagit och ännu synes vara i tilltagande samt för närwarande utgöres af Nio Hemmansegare, hwilka tillsammans med deras husfolk uppgå till omkring 35 à 40 personer; så anhöllo Svenskarne, att få Gudstjenst åtminstone fyra gånger om året samt dessutom Skrift 3 à 4 gånger. ${ }^{35}$
\end{abstract}

Kumlin, som år I842 kom till Östermark som kyrkoherde, verkar ha haft ganska exakt reda på att inte mindre än nio hemmansägare med hushåll kunde enbart svenska i hans församling och att antalet personer som inte kunde finska verkade tillta. I förteckningen över inflyttade till socknen åren I845 och I846 framgår att det har förekommit en inflyttning till Östermark från flera i huvudsak svenskspråkiga områden (till exempel Närpes, Pörtom, Lappfjärd och Sideby). ${ }^{36}$ Wallén har i sin tabell för Östermark år I846 angett antalet svenskar enligt det antal som i prostvisitationens protokoll angetts som enbart svenskkunniga. ${ }^{37}$ Mellan raderna i prostvisitationens protokoll kan man emellertid läsa att det i församlingen också fanns sådana som inte "endast äro det

35. Prostvisitationens protokoll 8-9/II I846 (§ 6, punkt m). ÖFA, Protokoll från prostvisitationer 1796-1857, del 50, Riksarkivet: http://digi.narc.fi/digi/view.ka?kuid $=8379280$ (hämtad I4/Io 2019).

36. ÖFA, Längder över till församlingen inflyttade I82I-I882, delar 75-77, s. I45-I50: Inflyttade I845-I846, Utflyttade I845-I846, Riksarkivet: http://digi.narc.fi/digi/view. ka?kuid=8379168-8379170 (hämtad I8/ır 2019).

37. Wallén, Språkgränsen och minoriteterna, s. 357 . 
Svenska språket mägtige”. De har också behärskat byns huvudspråk, finska. Som en följd av detta har de i likhet med de andra byborna kunnat delta i de finskspråkiga gudstjänsterna. För deras skull har man inte behövt ordna en separat svenskspråkig gudstjänst, medan "Svenskarne" i samband med prostvisitationen anhöll om att svenskspråkiga gudstjänster skulle hållas.

Detta väcker emellertid frågan om hur "svenskar" definierades som kategori år i846 eller dessförinnan. Termer anknutna till språk användes inte nödvändigtvis konsekvent. Till exempel nämns i slutet av I700-talet i matrikeln för Kristinestads pedagogium en finskspråkig elev, som av den som skrivit ner informationen beskrivs med orden "förut finne" men som sedan under läsåret förvärvat kunskaper i svenska. ${ }^{38} \mathrm{I}$ protokollet från prostvisitationen i Östermark den 6 maj I804 verkar det däremot som om "svenskar" betecknar dem som enbart kan svenska, men inte tvåspråkiga. I prostvisitationens protokoll (§ I3), vars information saknas i Holger Walléns tabell, ${ }^{39}$ berättas att:

Offentliga Gudstjensten hålles altid på finska språket, men skriftermål förrättas 2 a 3 gånger om året, på Svänska. Någon begäran anmältes at också få Svänsk predikan en eller annangång om året; men som icke med visshet nu utrönas kunde, huru stort antal af Svänskar är i Soknen; så kan Pastor i en framdeles skeende Soknestämma med säkerhet inhämta detta och föredraga ärendet Högvördige Dom kapitlet. De Svänskas antal måste eljest vara mycket litet; ungefär 9 a ro personer. ${ }^{40}$

Vid en första anblick verkar det inte finnas en särskilt klar uppfattning om antalet svenskspråkiga i församlingen, trots att prästerna på prostvisitationen borde ha känt till sina församlingsbor ganska väl. Av de närvarande hade kyrkoherden i Östermark Johan Forsman tjänst-

38. Uuno Pulkkila,"Kristiinankaupungin pedagogio. Kouluhistoriaa vuosilta I653-I842", A.A. Koskenjaakko et al. (toim.), Koulu ja menneisyys: Suomen koulubistoriallisen seuran vuosikirja 2, 1936, Porvoo \& Helsinki: WSOY I937, s. II5.

39. I Walléns tabell finns endast noteringar från åren I795 och I821. Wallén, Språkgränsen och minoriteterna, s. 357 .

40. Prostvisitationens protokoll 6/5 I804 (§ I3). ÖFA, Protokoll från prostvisitationer I796-I857, del 7, Riksarkivet: http://digi.narc.fi/digi/view.ka?kuid=8379239 (hämtad I7/I0 2019). 
gjort först som nådårspredikant från och med I766 och strax därefter som kaplan innan han 1795 utnämndes till kyrkoherde. Vid tillfället assisterades han av sin svärson, kyrkoherdeadjunkten Anders Gummerus (I769-I824) och även han hade kommit till församlingen redan år 1796. ${ }^{41}$ Utifrån textutdraget verkar det som om kyrkoherde Forsman och Gummerus inte räknade sin egen familjs fullvuxna medlemmar som "svänskar". Om dessa hade räknats in i gruppen av svenskar hade prästerna troligtvis lite noggrannare kunnat ange antalet svenskar i församlingen, eller en uppskattning om hur många de åtminstone var. När man beaktar vad som tidigare anförts om språkförhållandena i släkterna Forsman och Achtman är det troligt att förutom Wilhelm också dennes systrar Anna Maria Forsman (I775-I852) och Helena Margareta Forsman (I770-I823), av vilka den senare även var Gummerus hustru, utöver finska kunde åtminstone lite svenska. De antogs kanske inte vara "svänskar", även om de var ståndspersoner, eftersom de kunde följa en finskspråkig gudstjänst. En hänvisning till tvåspråkiga, som utan svårighet följde en finskspråkig gudstjänst, hittas också i ett prostvisitationsprotokoll uppgjort på kyrkoherde Cajanus tid och daterat den I7 maj I825. I protokollet står:

Svensk Gudstjenst hade hittils hvarken varit fordrad eller hållen; emedan de 18 à 20 Församlingens Medlemmar, som talade Svenska språket, voro i det Finska lika färdiga. [...] Antalet af dem, som inom Församlingen voro blott Svenska språket mägtige, besteg sig för det närvarande endast till $\mathrm{Fem} .{ }^{42}$

En hänvisning till ett anmärkningsvärt antal tvåspråkiga under I80o-talets första hälft hittas däremot i Carl Christian Böckers (I786-

4I. Om Gummerus, se Yrjö Kotivuori, "Ylioppilasmatrikkeli r640-I852: Anders Gummerus", nätpublikation 2005, https://ylioppilasmatrikkeli.helsinki.fi/henkilo. php?id=105I3 (hämtad I8/10 20I9).

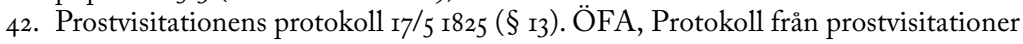
I796-I857, del 21, Riksarkivet: http://digi.narc.fi/digi/view.ka?kuid=8379252 (hämtad I8/Io 2019). Wallén, Språkgränsen och minoriteterna, s. 357, anger för år I825 antalet "svenskar" utifrån den grupp som i protokollet nämns som kunniga i både finska och svenska (I8-20 personer) och inte antalet personer som enbart talar svenska (5), medan han för år I846 i sin tabell anger antalet "Svenskar" utifrån dem som enbart kan svenska. 
I84I) statistik, enligt vilken det år I835 skulle ha funnits upp till 200 tvåspråkiga i Östermark. ${ }^{43}$ Böckers beräkningar har kritiserats och hans uppskattning om tvåspråkiga är förmodligen inexakt, ${ }^{44}$ även om den är intressant mot bakgrund av de källor som här har behandlats. Det material som tidigare presenterats och de tolkningar som gjorts utifrån det tyder i första hand på att de som enbart kunde svenska var relativt få i Östermark hela I8oo-talet igenom. Invånarantalet i Östermark beräknas ha ökat på I840-talet från att i början av decenniet ha varit lite över 3 ooo till att i början av I850-talet vara cirka $3800,{ }^{45}$ varvid det uppskattade antalet personer som enbart förstod svenska (35-40) som förekommer i 1846 års prostvisitationsprotokoll skulle ha utgjort cirka en procent av hela kyrksocknens befolkning. Dessa räknades till kategorin "svenskar", vars storlek det var väsentligt att räkna i officiell kontext, eftersom man utifrån detta kunde kräva svenskspråkig gudstjänst. Trots att de eventuellt är inexakta tyder Böckers beräkningar på att upp till fem procent av invånarna i Östermark kan ha varit tvåspråkiga. Deras modersmål kan ha varit svenska eller det kan ha funnits svenskspråkiga familjemedlemmar. Trots dessa tvåspråkiga i församlingen godkände man inte nödvändigtvis kraven på svenskspråkig gudstjänst. Inte ens den del av befolkningen som talade svenska ansåg alltid att kravet var nödvändigt. Så gick det till exempel på prostvisitationen den I7 maj I825, då den tidigare nämndemannen Ristiluoma enligt protokollet ( $\S_{13}$ ) föreslog "att Svensk Gudstjenst hädanefter åtminstone någon gång om året måtte hållas." Den tidigare nämndemannens förslag fick emellertid inte desto mera stöd och förföll därmed. ${ }^{46}$

Kyrkoherde Forsmans och adjunkt Gummerus tidigare uppskattningar om antalet svenskspråkiga år 1804 bestyrker observationer som

43. Se Wallén, Språkgränsen och minoriteterna, s. 357.

44. Om kritiken av Böcker, se t.ex. Kuvaja, "Språkkontakt och tvåspråkighet i I70ooch r8oo-talens Finland", s. 330-33I, 334-335.

45. Petri Ahola, "Myrkyn asutushistoria", Myrkky.fi-Myrkyn kylä, http://myrkky.fi/ kulttuuri/myrkyn-asutushistoria/ (hämtad 20/4 2020).

46. Prostvisitationens protokoll $\mathrm{I} 7 / 5 \mathrm{I} 825$ ( $\S_{13}$ ). ÖFA, Protokoll från prostvisitationer I796-I857, del 2I, Riksarkivet: http://digi.narc.fi/digi/view.ka?kuid=8379252 (hämtad I6/4 2020). I protokollsutdraget framgår inte om denne Ristiluoma själv var tvåspråkig (vilket är troligt) och om det $\mathrm{i}$ hans hushåll ingick tvåspråkiga eller enbart svenskkunniga. 
presenterats i tidigare forskning, enligt vilka förhållandet mellan språk och identitet inte har varit oföränderligt. Nils Erik Villstrand har framhållit hur språk och självbild på I7oo-talet inte ännu var intimt förknippade med varandra. Språkets roll som en del av identiteten förstärktes först på I8oo-talet bland fennomanerna och svekomanerna i samhällseliten. ${ }^{47}$ Kyrkoherdens och adjunktens uppskattning ger vid handen att enspråkighet och "svenskhet" inte utgjorde en väsentlig egenskap när det kom till att kategorisera en individ som ståndsperson i Östermark. Prästernas egna familjemedlemmar räknades inte in bland dem som var "svenskar". Wilhelm Forsman torde däremot ha hört till dem som enligt definitionen från I825 "talade svenska språket, [men] voro i det Finska lika färdiga”. Språket var i praktiken inte ett kriterium, på basis av vilket en individ i Östermark skulle ha definierats som ståndsperson eller icke ståndsperson. Troligtvis var "svenskarna" i Östermark både hemmansbrukare, pigor, drängar, hantverkare, soldater, torpare och husmän, det vill säga de torde alla ha hört till allmogen.

Det var kanske så att åtminstone ståndsmännen i Östermark i praktiken kunde både svenska och finska flytande, åtminstone så pass att de förmådde kommunicera med den allmoge som enbart talade finska. ${ }^{48}$ Tvåspråkighet var i sig inte heller en ståndsmarkör, eftersom det i Östermark, åtminstone $\mathrm{i}$ ljuset av Böckers material, måste ha funnits även tvåspråkig allmoge. I Östermark torde kanske det viktigaste kännetecknet på ståndstillhörighet, åtminstone ännu år I805, ha varit individens titel; till exempel nämns i Östermark församlings skrifteböcker åren 1804-1808 Wilhelms mor Elisabeth Forsmans ogifta syster som Mademoiselle ("Mademois:") Ulrica Achtman (I760-I8I2) och den tidigare nämnda Wilhelms syster Anna Maria Forsman likaså som Mademoiselle, medan Wilhelm å sin sida tituleras student ("Stud."). ${ }^{49}$

47. Villstrand, "Skriftlighet med förhinder", s. 350-35I.

48. Se även t.ex. Wassholm, Svenskt, finskt och ryskt, s. 77 .

49. ÖFA, Kommunionbok I798-I808 (IAa:5), del ır6: Prästgården Forsman, Riksarkivet: http://digi.narc.fi/digi/view.ka?kuid=7554966 (hämtad 20/4 2020). 
Den svenska som Wilhelm kunde som student var också de lärdas språk. Han hade nytta av att kunna svenska i officiella sammanhang, om det så var fråga om att göra upp dokument eller ett tillfälle där man muntligt behandlade officiella ärenden. Detta språk möjliggjorde att Wilhelm kunde sköta sin gamle fars ärenden på tinget och ansöka om lön av lönefordringskommittén. I vanligt och till sin natur informellare umgänge med människor i omgivningen använde man $\mathrm{i}$ Östermark talspråk, det vill säga lokala finska och svenska dialekter. ${ }^{50}$

Materialet ger bilden att Wilhelms starka förhållande till svenskan som uttryckligen de lärdas språk bevarades eller kanske till och med förstärktes när han blev äldre. Antydningar om detta hittas i Wilhelms eget bouppteckningsinstrument, uppgjort på finska den 8 maj 1865 . I bouppteckningen hittas den vaga noteringen "svenska böcker". ${ }^{51}$ I Östermark hade man tidvis uppgjort finskspråkiga bouppteckningsinstrument redan från och med 1840-talet; Wilhelms finskspråkiga bouppteckning var därmed inte längre ett undantag. ${ }^{52}$ Språket i bouppteckningsinstrumentet beskriver snarare Wilhelms efterkommandes och framför allt dokumentskrivarens förhållande till svenska. I uppteckningen specificeras inte vilka de svenska böckerna i fråga var. Det är möjligt att bland dem fanns böcker som Wilhelm själv hade införskaffat, men troligtvis också några av de "Böckar: Diwerse", som nämns år $1818 \mathrm{i}$ Wilhelms mor Elisabeth Forsmans bouppteckningsinstrument och som antagligen var ett arv efter hennes make Johan Forsman. ${ }^{53} \mathrm{Om}$ det är fråga om svenskspråkiga böcker som gått

50. Om svenska som skriv- och riksspråk i officiella sammanhang och som talspråk i officiella och inofficiella sammanhang samt som dialekt på 1500-I800-talet se Villstrand, "Skriftlighet med förhinder," s. 317-320; Om dialekterna i Närpes och Östermark och sambandet mellan dem, se Tamminen, Svensk påverkan på Teuvadialekten.

5I. Wilhelm Forsmans bouppteckningsinstrument 8/5 1865. Närpes domsagas arkiv (Riksarkivet i Vasa), Östermark tingslags bouppteckningar I867-I877 (E5c:I), del II2, Riksarkivet: http://digi.narc.fi/digi/view.ka?kuid=76915060 (hämtad ı2/3 2019).

52. Ranta,"Kirkkopitäjästä omaksi kunnaksi r796-I913", s. 388-393.

53. Elisabeth Forsmans bouppteckningsinstrument 3/4 I8I8. Korsholms södra domsaga, Korsholms södra domsagas arkiv (Riksarkivet i Vasa), Närpes och Östermark tingslags bouppteckningar: Närpes och Östermark tingslags bouppteckningar I8I7-I820 (E3a:5), del 240, s. 450, nr 2I6, Riksarkivet: http://digi.narc.fi/digi/view. ka?kuid=77I47390 (hämtad I9/Io 20I9). 
i arv kunde det faktum att de bevarades i släkten fram till Wilhelms död tolkas som att Wilhelm inte enbart satte värde på böckerna, utan också som en affektiv lojalitet - trohet - mot det nedärvda lärda ståndets språk och den världsbild som det förmedlade. På äldre dagar använde Wilhelm kanske inte längre svenska så ofta i vardagligt tal, men via böckerna bevarades förhållandet till svenskan och i synnerhet till det lärda ståndets språk och kultur. Enligt denna tolkning torde Wilhelms förhållande till svenskan inte (längre) ha varit enbart instrumentellt. Svenskan i böckerna skulle troligtvis också ha varit de många minnenas språk och samtidigt det språk som skilde honom från den lokala allmogen som talade finska eller svenska.

I bouppteckningsinstrumentet finns också en notering, enligt vilken all upptecknad egendom, inklusive Wilhelms böcker, såldes. Detta igen tyder kanske på att Wilhelms efterkommande dels behövde reda pengar, dels inte uppskattade den svenska litteraturen och i förlängningen svenskan lika högt som fadern. ${ }^{54}$ Det lärda ståndets litterära språk gick inte i arv, eftersom det inte togs emot - om det överhuvudtaget hade erbjudits dem medan fadern levde. ${ }^{55}$

De av Wilhelms barn som var närvarande vid uppgörandet av bouppteckningsinstrumentet, Carl Henrik (I8I3-I886) och Gretha Lisa (I8I2-I866) samt Clara Sofia (I8I6-I9I2) som representerades av sin man Samuel Matsson (senare Forsman, 1824-1903) har undertecknat dokumentet med bomärke i stället för med namnteckning. ${ }^{56}$ Valet av signatur visar på ett slags gränsdragning mellan fadern Wilhelms och hans barns språkförhållande; även om användandet av bomärke inte nödvändigtvis betydde att användaren inte kunde läsa och skriva, skiljer sig Wilhelms barns bruk från Wilhelms eget. Han undertecknade dokument med namnteckning och titulerade sig i samband

54. Antagligen har böckerna inte sålts av så kallat tvång, trots nödåren, eftersom man vid sidan av annan egendom enligt bouppteckningen också har sålt nio tunnor och sex kappar råg samt fyra tunnor och 2r kappar havre.

55. Utifrån det bevarade materialet är det i praktiken omöjligt att utreda till exempel krigserfarenhetens möjliga inverkan på Wilhelms verksamhet (eller overksamhet) efter kriget att vidareföra kunskaperna i svenska åt barnen.

56. Wilhelm Forsmans bouppteckningsinstrument 8/5 I865. Närpes domsaga, Närpes domsagas arkiv (Riksarkivet i Vasa), Östermark tingslags bouppteckningar, Östermark tingslags bouppteckningar I867-I877 (E5c:I), del II3, s. II4, Riksarkivet: http://digi.narc.fi/digi/view.ka?kuid=769I4884 (hämtad I9/II 20I9). 
med underteckningarna, vilket till exempel framkommer på ett intyg som berör faderns kaplanshyra och på det tidigare nämnda moderns bouppteckningsinstrument. ${ }^{57}$

Ett annat tecken på gränsdragningen mellan den lärda svenskspråkiga kulturen och allmogens finskspråkiga kultur är att ingendera av Wilhelms söner, Johan Wilhelm (I8Io-I84I) eller Carl Henrik, sändes iväg för att studera vid faderns gamla lärosäte Vasa trivialskola. De verkar inte heller ha studerat på Kristinestads pedagogium, där Carl Johan Achtman (född I782), son till Wilhelms morbror Alexander Achtman, tjänstgjorde som pedagog från och med I820 fram till sin död i lungsot $1834 .{ }^{58}$ Huvuddelen av eleverna på Kristinestads pedagogium utgjordes visserligen av stadsfamiljernas återväxt, men även föräldrar längre ut på landsbygden sände sina barn i lära. Enligt bevarade matrikeluppgifter och statistik över skolans intagna nya elever har tidvis även elever från Östermark sänts till Kristinestad. ${ }^{59}$

I pedagogium skedde undervisningen, precis som i trivialskolorna, på svenska. Det är svårt, om inte omöjligt, att utifrån källorna fastställa hur kunniga Wilhelms egna barn var i svenska. Även om Wilhelms barn inte skulle ha talat sin fars modersmål flytande finns det från motsvarande tid flera exempel på hur ursprungligen finskspråkiga barn har avklarat studier på pedagogierna och trivialskolorna

57. Om intyget på faderns kaplanshyra se ÖFA, Statliga myndigheters beslut om fastigheten I696-I86I, del 30: Register - år 1813, Riksarkivet: http://digi.narc.fi/ digi/view.ka?kuid=8379340 (hämtad 26/ro 20I9). Wilhelm titulerar sig i samband med underteckningarna sergeant.

58. Om Carl Johan Achtman, se Yrjö Kotivuori, "Ylioppilasmatrikkeli I640-I852: Karl Johan Achtman", nätpublikation 2005, https://ylioppilasmatrikkeli.helsinki. fi/henkilo.php?id=I2300 (hämtad 20/ro 20I9); notering i förteckningen över döda 28/2 I834. Kristinestads församling - Längder över födda och döpta I83I-I872, del 202, s. 6-7: Döde I834, Riksarkivet: http://digi.narc.fi/digi/view.ka?kuid=6981003 (hämtad 23/3 2020). Anmärkningsvärt är dock det faktum att elevantalet under C.J. Achtmans tid åren I82I-I833 var mycket lågt, i medeltal under Io. Pulkkila, "Kristiinankaupungin pedagogio", s. IO9-II2.

59. Om Kristinestads pedagogium, se Uuno Pulkkila, "Kristiinankaupungin pedagogio", s. I07. Bevarade matriklar från Kristinestads pedagogium finns först från och med år I827, men statistiken på intagna nya elever till skolan från åren I784-I844 innehåller uppgifter från tidigare år. 
i Österbotten. ${ }^{60}$ Men det kom även elever från familjer med hantverkar-, sjömans-, arbetar- och militärbakgrund till lärosätena, även om elever från en sådan bakgrund inte nödvändigtvis blev studenter. ${ }^{61}$ Forsmans släkt var å sin sida en av universitetssläkterna på I70o- och I8oo-talet; Wilhelm hade också fortsatt släktens tradition, och till exempel vid Vasa trivialskola erbjöds tidvis även ättlingar till utarmade prästsläkter möjligheten att fortsätta gamla traditioner. ${ }^{62}$

Till Wilhelms verksamhetsbild som kyrkväktare ingick dock att undervisa barn, ${ }^{63}$ och enligt protokollet från 1825 års prostvisitation

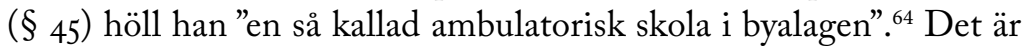
visserligen möjligt att Wilhelm genom att själv undervisa kan ha sett till att ge sina egna barn en tillräcklig läskunnighet - även om undervisningen i de ambulerande skolorna inte var avsedd att förbereda barnen för högre studier utan för skriftskola och läsförhör. ${ }^{65}$ Att Wilhelms barn använde sina respektive bomärken när de undertecknade bouppteckningsinstrumentet tyder å sin sida på att de inte fäste stor vikt vid skrivkunnighet.

Allmänt taget minskade behovet att sända landsbygdsbarnen i lära till stadspedagogierna när kyrkoherdarna i församlingarna började satsa på allmän läskunnighet. ${ }^{66}$ När församlingens undervisning var avklarad

6o. Se till exempel Knut Svanljung, Österbottens pedagogier och trivialskolor. Skolhistoriska studier, Helsingfors: [Knut Svanljung] I895, s. Ioo-ro6. Se också Suolahti,"Suomen kansallisuus- ja kieliolot I70o-luvulla," s. 296-297.

61. Kaarlo Jäntere, Koulunkäynti sosiaalisena ilmiönä vv. I722-I843 silmälläpitäen erityisesti Porin triviaalikoulua, Turku: Turun yliopisto 1927, s. 193-198; Sven-Erik Åström, Ståndssambälle och universitet. Universitetsbesöken som socialt fenomen $i$ Österbotten I722-I808, Helsingfors: [Helsingfors universitet] I950, s. I46-203.

62. Âström, Ståndssambälle och universitet, s. 203-204, 227-228.

63. Sockenstämmans protokoll 4 /ro I8I8 ( I-2). ÖFA, Socken- och kyrkostämmoprotokoll I804-I82I (IBa:I), del 8r; Riksarkivet: http://digi.narc.fi/digi/view. ka?kuid=755874I (hämtad I4/4 2020).

64. Prostvisitationens protokoll I7/5 I825 ( $\left.\S_{45}\right)$. ÖFA, Protokoll från prostvisitationer I796-I857, del 26, Riksarkivet: http://digi.narc.fi/digi/view.ka?kuid=8379257 (hämtad I9/II 20I9).

65. I de ambulerande skolarna gav man vanligtvis undervisning i innantilläsning, kristendomslära och räkning. Se till exempel Päivi Happonen, Sukututkimuksen asiakirjaopas. Väestöhistorialliset arkistolähteet, Mikkeli: Karjala-tietokantasäätiö 2004, s. I72-I73; Anna Kuismin,"Kiertokoulun ja kansakoulun välissä - Jacob Ahlsmanin kutsumus ja kriisi", Kasvatus E Aika 8, 20I4:2, s. 44-45.

66. Uuno Pulkkila,"Kristiinankaupungin pedagogio", s. IO8, III-II2. 
sände föräldrar som ville att barnen skulle lära sig för ett framtida yrke hellre sina barn till skolor där en sådan förberedning var möjlig, än till ett pedagogium. För till exempel Kristinestads pedagogiums del måste ändå konstateras att dess undervisning till innehållet och den praktiska nyttan verkar ha motsvarat trivialskolornas apologistklasser, som allmänt betraktades som "borgarskolor". Det är intressant att Wilhelm som ättling av en ståndssläkt inte sände sina barn i lära hos sin kusin och pedagog i staden, trots att skolstudier ofta också var vägen till en bättre samhällelig och ekonomisk ställning. ${ }^{67}$ För Wilhelms egna barn verkar kontakten till svenskan som uttryckligen de lärdas språk ha brutits helt.

En annan fråga är om avkomlingarna behärskade svenskt talspråk och i vilken grad de överhuvudtaget hade möjlighet att använda svenska. Hustrun Claras finskspråkighet kan ha inverkat på att man i Wilhelms familj talade enbart finska, även om familjens språk i det patriarkala samhället ofta bestämdes av faderns modersmål. Inom kort skulle de därpå följande generationernas språk emellertid ha blivit finska, såvida de inte hade tillräckligt med svenskspråkiga kontakter för att upprätthålla språkkunskapen. ${ }^{68}$ Så måste det ha gått senast när Wilhelms mor Elisabeth dog (I8I8), systern Helena Margareta flyttade med maken Anders Gummerus till Nivala (I8I4) och den andra systern Anna Maria dog (1852). Efter detta representerade närmast kyrkoherden och klockaren med familjer de ståndspersoner i Östermark, med vilka Wilhelms barn (eller Wilhelm själv) hade kunnat kommunicera regelbundet på svenska.

En antydan om att Wilhelms barn åtminstone behjälpligt kunde tala svenska är att två av dem senare flyttade till områden där behovet av finska var litet, eller som enligt Nils Erik Villstrands tanke kan definieras som en kontaktzon, där det förekom mycket tätt, till och med dagligt, umgänge mellan olika språkgrupper. ${ }^{69}$ Sådan var till exempel byn Mörtmark mellan Östermark och Lappfjärd, där det bodde både svensk- och finskspråkig befolkning, men vars förbindelser med

67. Ibid., s. IO6, II2, II9-I2I, I23, I28.

68. Allmänt om språkbyte och fastställande av hemspråk bland språkminoriteter, se Kuvaja, "Språkkontakt och tvåspråkighet i i7oo- och I8oo-talens Finland", s. 338.

69. Villstrand, Riksdelen, s. I2I; Kuvaja, "Språkkontakt och tvåspråkighet i i7oo- och I8oo-talens Finland", s. 326-327, 337 . 
det svenskspråkiga området vid kusten har varit livligare på grund av byns geografiska läge. ${ }^{70} \mathrm{~W}$ ilhelms dotter Gretha Lisa flyttade till Mörtmark efter att hon den 25 mars 1859 gifte sig med den lokala skomakaren Jakob Pelander (född I795). ${ }^{71}$ Wilhelms äldste, ogifte son Johan Wilhelm, som drunknade I84I, lämnade å sin sida Östermark år I83I för att bli dräng i Kristinestad, ${ }^{72}$ där behovet av finskakunskaper på den tiden inte var särdeles stort. ${ }^{73}$ Där började antalet finskspråkiga förmodligen öka först på I8oo-talet, eftersom man i staden endast höll svenskspråkiga gudstjänster fram till år I820, då en tiondel av befolkningen ansågs vara finskspråkig. ${ }^{74}$

Wilhelms dotter Clara Sofia flyttade år I869 från Kyrkoby till Perälä, till gården Kitti i Kråka nattbol, där familjen bodde de första åren under I870-talet. ${ }^{75}$ Som tidigare konstaterats var de svenskspråkiga i Östermark enligt Wallén till största delen koncentrerade till Perälä, men inte till hela byn utan i synnerhet just till Kråka nattbols område, som var känt under namnet Kråkby (fi. Krookankylä). Wallén hänvisar till en uppgift från I87o-talet, enligt vilken "några svenska familjer" vid den tiden ännu bodde i Kråkby. ${ }^{76}$ Uppgiften hänvisar inte nödvändigtvis till Clara Sofias familj, men i ljuset av den torde specifikt Kråkby (och i detta sammanhang I87o-talets Krågby) i byn Perälä definieras som en tvåspråkighetszon. Att Clara Sofia efter sina föräldrars död bosatte sig på ett område där den relativt sett största delen av den

70. Wallén, Språkgränsen och minoriteterna, s. 39-40.

7I. ÖFA, Vigsellängder I858-I88I, del 2, s. 4, 5: I858, I859, Riksarkivet: http://digi.narc. fi/digi/view.ka?kuid=837893I (hämtad I9/II 20I9); Lappfjärd församlings arkiv, Kommunionbok 1853-1859, del 224, sid 223: Mörtmark, Riksarkivet: http://digi. narc.fi/digi/view.ka?kuid=7068075 (hämtad I9/II 20I9).

72. No Io "Dreng. Johan Wilh. Forsman”. ÖFA, Längder över till församlingen inflyttade I82I-I882, del 39, s. 75, 76: Inflyttade I831, Utflyttade I831, Riksarkivet: http://digi.narc.fi/digi/view.ka?kuid=8379134 (hämtad 5/2 2019).

73. Kuvaja, "Språkkontakt och tvåspråkighet i I7oo- och I8oo-talens Finland”, s. 344.

74. Uuno Pulkkila, "Kristiinankaupungin pedagogio", s. II4. Enligt tabellen Wallén, Språkgränsen och minoriteterna, s. 4IO, skulle finskspråkiga gudstjänster börjat hållas i Kristinestad först från och med år 1872 .

75. ÖFA, Kommunionbok I864-I87ı, s. 69: Perälä by, Kråka nattbol, No 5, Kitti. Källa: FSHF, Teuva, https://www.sukuhistoria.fi/sshy/kirjat/Kirkonkirjat/teuva/teuva. htm (hämtad 23/4 2020); ÖFA, Kommunionbok I872-I88o, s. I03: Perälä by, Kråka nattbol, No 5, Kitti. Källa: FSHF, Teuva, https://www.sukuhistoria.fi/sshy/kirjat/ Kirkonkirjat/teuva/rippikirja_I872-I88o_mko159-I8I/IOo.htm (hämtad 23/4 2020).

76. Wallén, Språkgränsen och minoriteterna, s. 4I. 
svensk- eller tvåspråkiga befolkningen i Östermark bodde är i sig en intressant iakttagelse, även om det inte nödvändigtvis stärker ett antagande om att Clara Sofia möjligen kunde svenska. Som Johanna Wassholm därtill har påpekat ställde man i början på I8oo-talet ännu inte krav på renhet i språket, så man kunde också tala en blandning av finska och svenska. ${ }^{77}$ Lätta antydningar om ett sådant blandspråk i Östermark verkar ha bevarats fram till ıgoo-talet i den äldre Östermarkdialekten, som innehåller rikligt med inflytande från svenskan, inklusive direkta lån. ${ }^{78}$

Även om bedömningen av Wilhelms barns kunskaper i svenska på grund av de knappa källorna måste ses som endast spekulationer belyser de emellertid i någon mån Wilhelms förhållande till svenska. Wilhelms kunskaper i svenska band honom till de lärdas stånd och var därför delvis också ett tecken på hans stånd. Den svenska som antagligen åtminstone i någon mån gick i arv till hans barn skulle emellertid ha varit de ståndslösas språk, allmogens språk i likhet med finskan. Paradoxalt skulle det därmed också vara det språk som skilde Wilhelm från sina egna barn. Men samtidigt tyder barnens senare boningsorter på ett enhetligt och kontinuerligt språkförhållande mellan Wilhelms barn, Wilhelm själv och Wilhelms föräldrar; förhållandet till språk förblev mer eller mindre instrumentellt. Språket hade framför allt en social och kommunikativ funktion, och i Östermark, där största delen av växelverkan skedde med finskspråkiga, då och då med tvåspråkiga och endast sällan med svenskspråkiga, användes språket i enlighet med denna funktion.

\section{Avslutining}

Utifrån det material som här behandlats hade studenten, sergeanten, kyrkväktaren och torparen i Östermark Wilhelm Forsman, som dog år I865, ett i huvudsak instrumentellt förhållande till språk. För Wilhelm var både finskan och svenskan en resurs, som gjorde det möjligt att verka i olika sammanhang, såväl i trivialskolan, vid Akademien i Åbo, i finska kriget som i Östermark byagemenskap. Han förstod och blev

77. Wassholm, Svenskt, finskt och ryskt, s. 77-78.

78. Se t.ex. Tamminen, Svensk påverkan på Teuvadialekten, s. 5I-57. 
förstådd oberoende av kontext. I ljuset av tidigare forskning torde språket inte ha utgjort ett väsentligt drag i hans självbild, även om en aktiv tvåspråkighet - $\mathrm{i}$ synnerhet att individen $\mathrm{i}$ officiella sammanhang behärskade svenska - var en färdighet som speciellt förknippades med ståndspersoner. Etnicitet var för honom troligtvis inte av lika stor betydelse som stånd och de titlar och den livsstil som förknippades med ståndet, och dessa tre faktorer sammantaget skilde honom från vanlig allmoge.

Svenskan som de lärdas språk i släkten på både fädernet och mödernet torde emellertid även ha varit ett språk av emotionell betydelse för den före detta studenten Wilhelm. När Wilhelm blev äldre torde språket redan ha varit förknippat med många minnen, och som litterärt språk torde svenskan även ha skilt honom från allmogen som talade den lokala svenska dialekten. Antydningar om ett emotionellt förhållande till språk ger också de "svenska böcker" som han bevarade livet ut, vilka emellertid inte längre hade ett affektionsvärde för hans egna barn.

Man kan spekulera i om Wilhelm mera målmedvetet skulle ha överfört färdigheten i svenska, inklusive förmågan att använda språket i litterära och officiella sammanhang, till sina barn om svenskan i Östermark kraftigare skulle ha förknippats med stånd, och inte bara betraktats som ett språk som de civila och kyrkliga tjänsteinnehavarna i Östermark och Närpes, i tillägg till den svenskspråkiga allmogen i trakten, behärskade. I ljuset av det som tidigare presenterats kunde Wilhelms efterkommande antagligen tala svenska, eller en blandning av finska och svenska - eller den lokala dialekten, som troligtvis redan på I8oo-talet innehöll många influenser från svenskan och i synnerhet Närpesdialekten. De slog emellertid inte in på den lärda banan, och svenskan som de lärdas språk och i många fall en garanti för en bättre inkomst förmedlades inte till Wilhelms barn.

I denna undersökning har också problemet med att kategorisera framkommit, det vill säga hur svårt det överhuvudtaget är att definiera och bedöma människors språk och etnicitet i det förflutna utifrån officiellt material. Under en tid när man ännu inte fäste så stor vikt vid språklig renhet och när språket främst har haft en social och kommunikativ funktion i stället för att definiera identitet kan olika grader av tvåspråkighet ha varit allmän på områden där språken kom 
i kontakt med varandra. De lokala dialekterna kan även de berätta om förekomsten av en viss tvåspråkighet under den tid som dialekten formades. Att avgöra vilken språkgrupp en individ i det förflutna har tillhört eller ansett sig tillhöra har inte (heller) varit enkelt.

Där svenskan för Wilhelm var bildningens och det lärda ståndets språk blev svenskan för hans barn, som var drängar och pigor, allmogens språk. I kontinuiteten från släktled till släktled finner vi Wilhelm i ett gränsområde, där han å ena sidan hade det förflutnas tvåspråkighet och ståndstillhörighet och å den andra en framtida enspråkig finskhet och avsaknad av ståndstillhörighet.

Översättning till svenska av Elisabeth Stubb 